\title{
Pengajaran noun-pronoun agreement bagi mahasiswa Business English
}

\author{
Hasriani G. ${ }^{1}$, Mardiyanah Nasta ${ }^{2}$ \\ ${ }^{1,2}$ Fakultas Bahasa dan Sastra, Universitas Negeri Makassar
}

\begin{abstract}
The partner of this service program was the second semester students of Business English Study Program, Faculty of Language and Literature, State University of Makassar. The problem of partner was the lack of knowledge regarding conformity between noun and pronoun in an English sentence so that they continue to make mistakes in writing or expressing an English sentences. The expected outcome was the students have an understanding of noun-pronoun agreements in English and can make English sentences correctly both in oral and written form. The approach used in conducting this program consisted of two methods, namely the presentation and practice. The results achieved were the participants (1) have knowledge and understanding that are likely not at the same level regarding the basic theories of noun-pronoun agreement, (2) are able to adjust between pronoun with the noun that precedes the pronoun (antecedent) in an English sentence, and (3) around 95\% are able to do exercises in accordance with the theories in oral or written form even though some of them or about $5 \%$ are sometimes still wrong in writing or saying the sentence in English.
\end{abstract}

Keywords: noun-pronoun agreement, business english

\section{PENDAHULUAN}

Salah satu program studi pada jurusan Bahasa Inggris, Fakultas Bahasa dan Sastra Universitas Negeri Makassar adalah Bahasa Inggris D3 atau yang lebih familiar dengan sebutan Business English. Pada program studi ini, matakuliah keterampilan dan komponen bahasa juga menjadi matakuliah yang wajib karena menjadi jembatan bagi mahasiswa dalam memahami konten dari setiap materi yang mereka pelajari pada matakuliah yang sifatnya spesifik berdasarkan program studi mereka atau English for Spesifc Purposes (ESP).

Selama ini mahasiswa Business English banyak menemui kendala dalam belajar bahasa Inggris, terutama dalam memahami komponen bahasa, dalam hal ini grammar dan vocabulary. Menurut hasil wawancara dengan beberapa orang mahasiswa, mereka mengakui bahwa kendala terbesar mereka dalam belajar adalah penguasaan kosa kata dan pemahaman grammar yang kemudian menjadi kendala bagi mereka untuk dapat menguasai keterampilan berbahasa Inggris. Dalam hal pemahaman grammar, salah satu kesalahan yang sering dilakukan oleh mahasiswa adalah ketidak kesesuaian antara noun dan pronoun dalam sebuah kalimat, baik secara lisan maupun tulisan. Hal tersebut tidak dapat dibiarkan begitu saja mengingat noun-pronoun agreement merupakan pengetahuan dasar yang cukup penting.

Dalam rangka mengatasi permasalahan tersebut di atas, maka perlu diadakan pelatihan khusus yang terfokus pada pembahasan materi nounpronoun agreement. Melalui pelatihan tersebut, diharapkan bahwa mahasiswa akan terbantu dalam menguasai keterampilan Bahasa Inggris dengan adanya pemahaman mengenai materi nounpronoun agreement.

Hal tersebut di atas yang melatarbelakangi sehingga tim penulis melaksanakan pengabdian kepada masyarakat bagi mahasiswa semester dua (II) Program Studi Business English, Fakultas Bahasa dan Sastra, Universitas Negeri Makassar. Pengabdian ini dilaksanakan dengan menyajikan materi noun-pronoun agreement selama 5 kali pertemuan. Pelatihan ini diharapkan dapat memberikan pengetahuan serta pengalaman bagi mahasiswa mengenai kesesuaian antara noun dan pronoun dalam sebuah kalimat bahasa Inggris, baik secara lisan maupun tulisan sehingga hal tersebut dapat memberikan kemudahan bagi 
mahasiswa pada saat berkomunikasi menggunakan bahasa Inggris.

Berdasarkan gambaran di atas, yang menjadi permasalahan mitra adalah kurangnya pengetahuan mahasiswa semester dua (II) Program Studi Business English, Fakultas Bahasa dan Sastra, Universitas Negeri Makassar mengenai kesesuain antara noun dan pronoun dalam sebuah kalimat bahasa Inggris sehingga mereka terus menerus melakukan kesalahan dalam membuat atau mengungkapkan kalimat Bahasa Inggris. Hal tersebut tentu saja membutuhkan solusi mengingat pentingnya pemahaman mengenai noun-pronoun agreement dalam Bahasa Inggris.

\section{METODE PELAKSANAAN}

Pendekatan yang ditawarkan dalam pelaksanaan pelatihan terdiri dari dua metode. Yang pertama adalah penyajian materi. Materi yang diajarkan dalam kegiatan pelatihan ini diambil dari berbagai sumber yang relevan mengenai noun-pronoun agreement. Adapun materi yang disajikan dalam pengajaran antara lain pengertian mengenai nounpronoun agreement dan pronoun types (Devani, 2017), materi tentang agreement in place, number and gender (Hunt, 2016), materi mengenai common mistake in noun-pronoun agreement (Hariyono, 2012) dan materi mengenai pronoun as an antecedent (Webster, 2016). Materi disajikan melalui PowerPoint presentation dilengkapi dengan video yang berisi tentang materi nounpronoun agreement. Setelah penyajian materi, para peserta diberi kesempatan untuk menanyakan halhal yang belum dimengerti atau hal yang ingin diketahui mengenai materi yang telah disajikan oleh pemateri. Kegiatan ini bertujuan untuk memberikan mahasiswa pengetahuan dan pemahaman mengenai materi noun-prounoun agreement dalam kalimat bahasa Inggris.

Metode pendekatan yang kedua adalah pemberian latihan. Pada setiap akhir penyajian materi, peserta diberi latihan untuk memastikan pemahaman mereka mengenai materi yang disajikan pada setiap pertemuan. Dalam kegiatan ini, tim penulis memberikan latihan tertulis berupa kalimat Bahasa Inggris yang noun dan pronounnya tidak sesuai untuk kemudian disesuaikan oleh para peserta pelatihan. Setelah latihan dalam bentuk tertulis, tim pelaksana kemudian memberikan latihan secara lisan. Dalam kegiatan ini, pemateri mengungkapkan kalimat sederhana dalam Bahasa Indonesia, kemudian diungkapkan kembali dalam Bahasa Inggris oleh peserta pelatihan. Kedua kegiatan tersebut dimaksudkan untuk memastikan bahwa peserta memeroleh pengetahuan dan pemahaman mengenai materi nounpronoun agreement sesuai target yang ingin dicapai. Pada setiap kegiatan, kerjasama dari tim pelaksana sangat membantu kelancaran pelaksanaan program pengabdian ini. Tim pelaksana selalu siap siaga membimbing para peserta jika dibutuhkan.

\section{HASIL DAN PEMBAHASAN}

Kegiatan pengabdian kepada masyarakat dalam bentuk pengajaran Noun-Pronoun Agreement dalam kalimat Bahasa Inggris ini dilaksanakan sebanyak lima (4) kali pertemuan setiap hari Rabu pada bulan Juni, 2019. Peserta terdiri dari 31 orang. Kegiatan ini merupakan salah satu penawaran solusi yang diberikan kepada peserta tersebut di atas dan dikemas dalam beberapa fase kegiatan sebagai berikut.

1. Fase pertama

Materi pelatihan dikemas dengan presentasi verbal dan visual. Ini menandakan bahwa aplikasi metode ceramah akan dilakukan dengan penggunaan fasilitas informasi dan teknologi, yaitu LCD yang dimaksudkan untuk menyajikan materi secara detail mengenai subject-verb agreement beserta contoh-contoh yang diharapkan menjembatani pemahaman para peserta pelatihan.

\section{Fase kedua}

Tim penulis memberikan latihan tertulis berupa kalimat Bahasa Inggris (present tense) yang noun dan pronoun-nya tidak sesuai untuk kemudian disesuaikan oleh para peserta pelatihan. 


\section{Fase ketiga}

Setelah latihan dalam bentuk tertulis, tim penulis kemudian memberikan latihan secara lisan. Dalam kegiatan ini, pemateri mengungkapkan kalimat sederhana dalam Bahasa Indonesia, kemudian diungkapkan kembali dalam Bahasa Inggris oleh peserta pelatihan.

\section{Fase keempat}

Dalam kegiatan terakhir, peserta pelatihan diminta untuk membuat beberapa contoh kalimat Bahasa Inggris untuk memastikan pemahaman peserta mengenai materi noun-pronoun agreement yang telah disajikan pada pertemuan sebelumnya.

Tim pelaksana menargetkan dua (2) pencapaian kompetensi/kemampuan peserta sebagai objek utama pada pelatihan ini yaitu (1) Pemahaman mengenai noun-pronoun agreement dalam Bahasa Inggris dan (2) Kemampuan untuk membuat kalimat Bahasa Inggris dengan benar secara lisan maupun tertulis.

Kedua target tersebut di atas berhasil diraih oleh peserta selama pelatihan yang berlangsung selama 5 (kali) kali pertemuan dengan durasi 100 menit untuk setiap pertemuan, setiap hari Rabu pada bulan April dan Mei 2019. Ini menandakan bahwa peserta, yaitu mahasiswa mahasiswa semester dua (II) Program Studi Program Studi Bahasa Inggris DIII atau Business English, Jurusan Bahasa Inggris, Fakultas Bahasa dan Sastra, Universitas Negeri Makassar telah memahami secara teoritis dan mampu mengaplikasikan pengetahuan dan pemahaman mereka mengenai materi noun-pronoun agreement dalam struktur kalimat Bahasa Inggris.

Deskripsi pencapaian hasil pelatihan tersebut di atas menunjukkan bahwa peserta pelatihan (1) memiliki pengetahuan dan pemahaman yang kemungkinan besar tidak berada pada level yang sama mengenai teori-teori dasar noun-pronoun agreement, (2) mampu menyesuaikan antara kata ganti (pronoun) dengan kata yang mendahului kata ganti tersebut (antecedent) dalam sebuah kalimat bahasa Inggris, dan (3) sekitar 95\% mampu mengerjakan latihan yang sesuai dengan teori-teori tersebut dalam bentuk lisan maupun tulisan meski beberapa diantara mereka atau sekitar 5\% terkadang masih keliru dalam menuliskan atau mengucapkan kalimat yang benar dalam bahasa Inggris.

Program Studi Bahasa Inggris DIII atau Business English, Jurusan Bahasa Inggris, Fakultas Bahasa dan Sastra, Universitas Negeri Makassar yang berjumlah 31 orang terdiri atas 29 orang perempuan dan 2 orang laki-laki sebagai peserta pelatihan ini kemungkinan besar telah memperoleh pengetahuan mengenai penyusunan kalimat yang benar dalam Bahasa Inggris, namun ada beberapa faktor yang kemungkinan menjadi alasan sehingga para peserta terkadang masih keliru dalam menyesuaikan antara antecedent dan pronoun dalam sebuah kalimat bahasa Inggris.

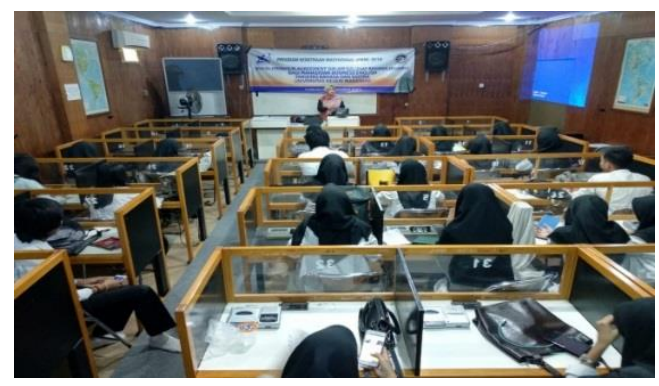

Gambar 1. Pertemuan I

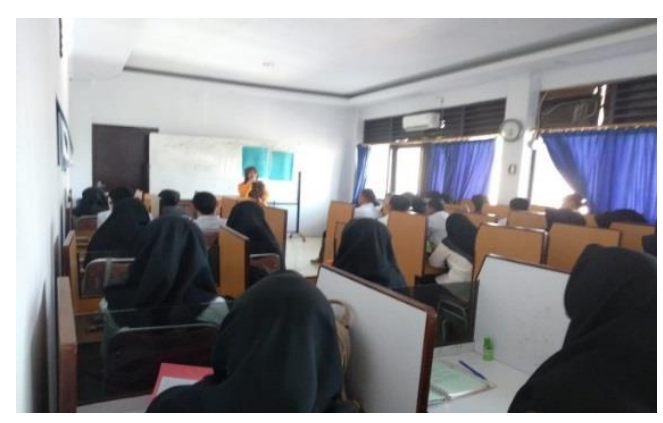

Gambar 2. Pertemuan II

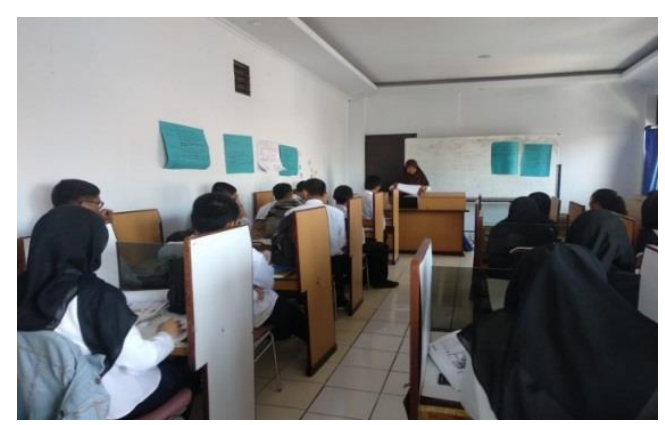

Gambar 3. Pertemuan III 


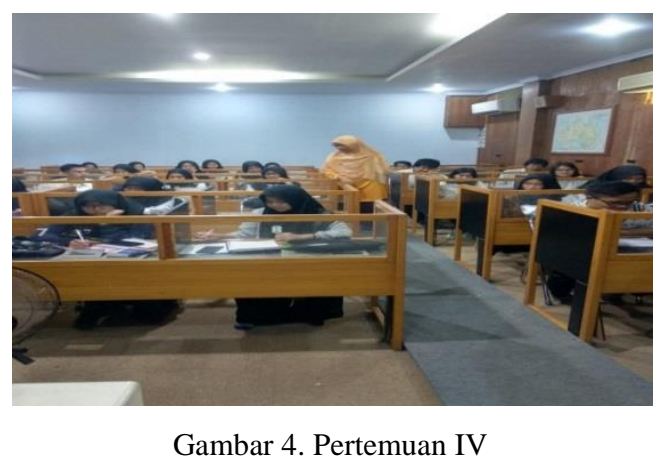

\section{KESIMPULAN}

Pelaksanaan pelatihan ini berjalan sesuai dengan perencanaan dan prosedur program atau kegiatan yang disusun secara kolaboratif oleh tim pelaksana yang bisa menarik partisipasi aktif peserta. Keaktifan peserta diindikasikan oleh sikap positif, motivasi, rasa percaya diri, dan tanggungjawab melaksanakan latihan-latihan dan tugas-tugas yang mendukung pengetahuan dan pemahaman mereka mengenai noun-pronoun agreement. Peserta memeroleh pengetahuan dan pemahaman tentang kesesuaian antara kata ganti (pronoun) dengan kata yang mendahului kata ganti tersebut (antecedent) dalam kalimat bahasa Inggris. Peserta pelatihan dengan estimasi sekitar 95\% mampu mengaplikasikan pengetahuan dan pemahaman mereka, yakni mampu menulis dan mengungkapkan kalimat present tense dengan baik dan benar dan sekitar 5\% masih memiliki kesalahan.

\section{UCAPAN TERIMA KASIH}

Keberhasilan pelaksanaan pelatihan ini tidak terlepas dari bantuan berbagai pihak. Oleh karena itu, penulis menyampaikan rasa terima kasih yang sedalam-dalamnya kepada Rektor Universitas Negeri Makassar; Ketua Lembaga Penelitian dan Pengabdian Masyarakat Universitas Negeri Makassar yang telah memberikan kepercayaan untuk melaksanakan program kemitraan masyarakat ini; Mahasiswa Business English semester (II) atas kerjasama yang baik karena telah mengikuti pelatihan dengan kesungguhan dan semangat yang tinggi; dan semua pihak yang telah turut membantu menyukseskan kegiatan pelatihan ini. Semoga kita semua senantiasa diberi kesehatan dan kemudahan oleh Allah SWT sehingga kedepannya dapat melaksanakan kegiatan bermanfaat di waktu dan tempat yang berbeda.

\section{DAFTAR PUSTAKA}

Devani, 2017. Pengertian Pronoun Agreement dan Contoh. https://azbahasainggris.com/pengertian-pronounagreement.

Hariyono, Rudy. 2002. Complete English Grammar. Surabaya: Gitamedia Press.

Hunt, Angela C. English Use for Business Writing. California: Los Angeles County.

Webster, M. W. (Ed.). (2006). Webster's English Usage Guide. Springfield, MA: Federal Street Press. 